Eng. Appl. Sci. Lett., Vol. 1(2018), No. 2, pp. 01 - 09

Website: https://pisrt.org/psr-press/journals/easl/

ISSN: 2617-9709 (Online) 2617-9695 (Print)

http://dx.doi.org/10.30538/psrp-easl2018.0006

\title{
IN VITRO COMPARISON OF DIFFERENT BRANDS OF CETIRIZINE 2HCl TABLETS BY SPECTROSCOPY AND THIN LAYER CHROMATOGRAPHY (TLC) IN LOCAL MARKET OF LAHORE, PAKISTAN
}

\author{
SAJID MAHMOOD ${ }^{1}$, AMMARA RAFIQ, ZAHEER AHMED, MUHAMMAD AJMAL
}

\begin{abstract}
The objective of the present study is to investigate and compare the efficacy, physiochemical equivalence and purity of API's of different brands of cetirizine $2 \mathrm{HCl}$ tablets $(10 \mathrm{mg})$ with that of multinational brands available in local market of Lahore, Pakistan. The present work also provides awareness to allergy patients about most effective local brands with reasonable prices, without any health risk. Spectrophotometric method is used for chemical assay, TLC technique is subjected for the purity of API's and physiochemical parameters is employed i.e. weight variation, hardness, friability, thickness, disintegration time and dissolution study as well as price fluctuation in PK rupees. The results of all physiochemical parameters and chemical assay are found to be within limit and meet to the pharmacopeial standards. TLC technique is developed to check the quality and purity of API, all the active ingredients showed the similar $R_{f}$-values without any impurity (0.38-0.39). From the test results and plots, it is observed and concluded that an economical and quality products can be prescribed for allergy patients whether they are manufactured by the local or multinational pharmaceutical companies without any health risk.
\end{abstract}

Index Terms: Cetirizine 2HCl; comparative analysis; spectroscopy; TLC; physiochemical parameters.

Received 14-10-2018. Accepted 10-11-2018

1 Corresponding Author

(C) 2018 Sajid Mahmood, Ammara Rafiq, Zaheer Ahmad, Muhammad Ajmal. This is an open access article distributed under the Creative Commons Attribution License, which permits unrestricted use, distribution, and reproduction in any medium, provided the original work is properly cited. 


\section{Introduction}

Tablets and capsules represent unit dosage forms whereas liquid oral dosage forms such as syrups, suspensions, emulsions, solutions and elixirs usually contain one dose of medication in 5 to $30 \mathrm{~mL}$. Such doses are erratic by a factor ranging from 20 to $50 \%$ when the drug is self-administered by the patient [1. The oral route of drug administration is the most important method for systemic effects. Solid oral dosage forms (tablet and capsule) are the preferred class of products of the two forms, the tablet has a number of advantages such as the tablet is an essentially tamper proof dosage form [2, 3. Cetirizine is the carboxylated metabolite of hydroxyzine, and has high specific affinity for histamine H-receptors. Cetirizine dihydrochloride (CZ) is (RS)-2-[2-[4-[(4-chlorophenyl) phenyl methyl] piperazine-1-yl]ethoxy] acetic acid dihydrochloride. It is used for the symptomatic relief of allergic conditions including rhinitis and chronic urticarial [4, 5].

Literature survey shows comparative study of different brands of the same generic of pharmaceutical dosage form, and have indicated that pharmaceutical evaluation of different brands are as important as biological and clinical equivalency.

It is generally evaluated that many drugs that are manufactured in developing countries are implicated to be substandard [6]. To improve the quality of health products and to minimize the health risk factors. It is necessary to monitor all the pharmaceutical services in a regular basis that promoting the conditions and providing information on the base of which the people become enable to make healthy choices and they can make correct decisions about their health. Many tests are frequently applied to tablet dosage forms to render their optimum therapeutic effects. The technique of optimization is well reported in the literature for the development of tablet formulations $[7,8,9$. The purpose of carrying out optimization is to select the best possible formulation from a pharmaceutical as well as consumer point of view.

In the context above we have made an attempt to compare all the physical and chemical parameters including purity of API's of five different brands of cetirizine $2 \mathrm{HCl}$ tablet available in local market of Lahore, Pakistan with that of multinational brand on the basis of GMP, GLP and Pharmcopial standards. Since no work has so far been carried out in the said perspective. Therefore we choosed this topic and to decide to provide awareness to allergy patients about most effective local brands with reasonable prices, without any health risk.

\section{Materials and Methods}

Reference cetirizine $2 \mathrm{HCl}$ was a kind gift sample from Jawa pharmaceuticals (pvt) Ltd. Lahore, Pakistan. Different brands of cetirizine $2 \mathrm{HCl}$ were obtained from different retail pharmacies of Lahore (Pakistan) and their qualitative and quantitative tests are carried out.

Zyrtec (UCB Farchim, S.A, Switzerland)

Alergo (Pharmix laboratories) 
Cetrix (Saffron Pharmaceuticals)

Instazin (Friends Pharma )

Tryzin (Pulse pharmaceuticals).

\section{Experimental}

Spectrophotometer (Shimadzu UV-1800), Disintegration apparatus (IPL - 27 model) Hot plate with magnetic stirrer (78-1) Hardness tester (PAK/HT-0607), Friability apparatus (Betatek EF-2), Weighing balance (Japan), micropipette, Hydrochloric acid (Merck Germany), and freshly prepared distilled water are used for the this study. Reasonable availability of medicine requires that a medicine should fulfill the clinical needs of a patient for an adequate period of time, at the lowest cost to them and their community. Various pharmaceutical parameters were employed as in USP 31 (2008), i.e. thickness, hardness, weight variation, friability, disintegration, and dissolution, to test the different brands of cetirizine hydrochloride tablets available.

3.1. Price Fluctuation. The most effective local brands with reasonable prices, without any health risk also provide awareness to the allergic patient in our community. Label information and price fluctuation among different brands of cetirizine $2 \mathrm{HCl}$ are given in Table 1.

TABLE 1. Label information of different brands of cetirizine $2 \mathrm{HCl}$ tablets (10mg)

\begin{tabular}{|c|c|c|c|c|c|c|}
\hline $\begin{array}{l}\mathrm{Sr} \\
\mathrm{No}\end{array}$ & $\begin{array}{l}\text { Product } \\
\text { Name }\end{array}$ & $\begin{array}{l}\text { Menufactured } \\
\text { by }\end{array}$ & $\begin{array}{l}\text { Batch } \\
\text { No }\end{array}$ & $\begin{array}{l}\text { Mfg } \\
\text { date }\end{array}$ & $\begin{array}{l}\text { Exp } \\
\text { date }\end{array}$ & $\begin{array}{l}\text { Price } / 10 \\
\text { tab }\end{array}$ \\
\hline 1 & Zyrtec & $\begin{array}{l}\text { UCB Farchim, } \\
\text { S.A, Switzerland }\end{array}$ & HZXAP & 04-2018 & 04-2020 & 42.00 \\
\hline 2 & Alergo & $\begin{array}{l}\text { Pharmix } \\
\text { laboratories } \\
\text { (Pvt) Ltd }\end{array}$ & $\mathrm{C} 824$ & 03-2018 & 02-2021 & 39.00 \\
\hline 3 & Cetrix & $\begin{array}{l}\text { Saffron } \\
\text { Pharmaceuticals } \\
\text { (Pvt)Ltd }\end{array}$ & 106 & $11-16$ & 10-19 & 28.00 \\
\hline 4 & Instazin & $\begin{array}{l}\text { Friends } \\
\text { Pharma (Pvt)Ltd }\end{array}$ & 18IN021 & 08-2018 & 08-2021 & 42.00 \\
\hline 5 & Tryzin & $\begin{array}{l}\text { Pulse } \\
\text { pharmaceuticals } \\
\text { (pvt)Ltd }\end{array}$ & 1298 & 11-2018 & $10-2021$ & 30.00 \\
\hline
\end{tabular}

3.2. Thickness and Diameter. Thickness of tablet can vary without any change in its weight because of difference in the density of the granulation and the pressure applied to the tablets as well as speed of tablet compression. The 
thickness variation limits allowed are $5 \%$ of the size of the tablet [10, 11. Vernier calipers were used to determine the thickness of 20 tablets. Table 2. shows mean S.D. of each brand tested.

3.3. Hardness Test. Hardness of the tablet is controlled by compression machine by applying the degree of pressure in $\mathrm{Kg} / \mathrm{cm} 2$ during granules compression. This parameter is very important because it effects disintegration time and dissolution profile [12] A hardness tester (PAK/HT-0607)is used for 20 tablets randomly and mean standard deviation S. D. of each brand of cetirizine hydrochloride is calculated which shows in Table 2.

3.4. Weight variation. The weight of the tablet dosage form is measured to check the proper amount of the active ingredient in the tablet. Analytical grade weighing balance is used to measure the individual as well as average weight of the tablet and mean standard deviation S.D. of each brand of cetirizine hydrochloride is calculated which shows in Table 2 .

3.5. Disintegration Time. Disintegrations are required to break up tablets into fine powder in order to increase surface area of drugs exposed to gastrointestinal fluids. Disintegration test is conducted by disintegration apparatus (IPL-27) on different brands of cetirizine $2 \mathrm{HCl} 10 \mathrm{mg}$ tablets and it is found that all tablets of each brand disintegrated within the range of 04-22 minutes. Figure 3 indicates that product Instazin has shown a maximum average disintegration time about 22 minutes and sample Tryzin has shown minimum disintegration time about 2 minutes which is best as compare to other products. The disintegration test do serve as a component in the overall quality control of the tablets manufacturing. The results are shown in Table 3.

3.6. Friability Test. The friability test is designed to evaluate the ability of the tablet to withstand breakage during packaging, handling, and shipping. After physical inspection and dusting, ten tablets are weighed and placed in the friability apparatus (Betatek EF-2) where they are exposed to rolling and repeated shocks as they fall 6 inches in each tern within the apparatus. After 100 revolutions, the tablets are weighed and the weight is compared with the initial weight. The loss due to abrasion is a measure of tablet friability. Maximum weight loss is not more than $1 \%$ of the initial weight of the tablet. All the results are shown in Table 2.

3.7. Thin Layer Chromatography (TLC). Thin layer chromatography is used to separate, identify and purify of the compound or drug content. The $R_{f}$ value of a particular pure analyte in a particular solvent (or mixture) is constant if the experimental conditions i.e. temperature, chromatography medium, solvent concentration and purity, amount of sample spotted on chromatography medium are kept unaltered. Thin layer chromatography is subject to check the specificity and purity of cetirizine hydrochloride in all brands by using solvent system ethyl acetate: methanol: formic acid (7.5:1.5:0.5 v/v/v) and compared 
it by Co-TLC with the standard. It is found that the active drug in all the brands showed single spot $\left(R_{f}\right.$ values 0.38$)$ after visualization on TLC plate which confirmed the purity and specificity of the drug and it was also noted that no interference of any component on TLC was observed.

3.8. Preparation of Sample and Standard Solution. An accurately weighed $10 \mathrm{mg}$ cetirizine $2 \mathrm{HCl}$ (reference standards) is transferred to $100 \mathrm{~mL}$ volumetric flask and dissolved in $0.1 \mathrm{~N} \mathrm{HCl}$ and make up the volume up to the mark with the same solvent to obtain standard solution having concentration 1000ppm. Magnetic stirrer is used for better dissolution. Further 10ppm dissolution is made by taking $1 \mathrm{~mL}$ from the above solution and make up the volume to $100 \mathrm{~mL}$ with $0.1 \mathrm{~N} \mathrm{HCl}$.

The standard solution of cetirizine $2 \mathrm{HCl}$ is made by dissolving $10 \mathrm{mg}$ of pure cetirizine $2 \mathrm{HCl}$ in $100 \mathrm{~mL}$ of $0.1 \mathrm{~N} \mathrm{HCl}$. Magnetic stirrer is used for better dissolution. Further 10ppm dissolution is made by taking $1 \mathrm{~mL}$ from the above solution and make up the volume to $100 \mathrm{~mL}$ with $0.1 \mathrm{~N} \mathrm{HCl}$.

3.9. Content Assay. Every tablet contains the amount of active ingredient claimed, which can vary among the tablets within a batch. Analysis of drug potency in tablet not only indicating the presence of drug in dosage form but also shows its stability. For the evaluation of content, assay has been performed. The chemical assay results showed that all the five brands have active ingredient amount within limits i.e $90-110 \%$.

TABle 2. Physiochemical Parameter of Cetirizine 2HCl Tablets

\begin{tabular}{|l|l|l|l|l|l|}
\hline $\begin{array}{l}\text { Brand } \\
\text { names }\end{array}$ & $\begin{array}{l}\text { Thickness } \\
(\mathrm{mm})\end{array}$ & $\begin{array}{l}\text { Diameter } \\
(\mathrm{mm})\end{array}$ & $\begin{array}{l}\text { Hardness } \\
\text { test }(\mathrm{kg} / \mathrm{cm} 2)\end{array}$ & $\begin{array}{l}\text { Weight } \\
\text { variation } \\
(\mathrm{mg})\end{array}$ & $\begin{array}{l}\text { Friability } \\
\text { test (\%age) }\end{array}$ \\
\hline Zyrtec & $2.71 \mathrm{~mm}$ & $4.10 \mathrm{~mm}$ & $\begin{array}{l}3.08 \\
\mathrm{~kg} / \mathrm{cm} 2\end{array}$ & $\begin{array}{l}118 \\
\mathrm{mg}\end{array}$ & NMT $1 \%$ \\
\hline Alergo & $3.51 \mathrm{~mm}$ & $5.55 \mathrm{~mm}$ & $3.46 \mathrm{~kg} / \mathrm{cm} 2$ & $\begin{array}{l}150 \\
\mathrm{mg}\end{array}$ & NMT $1 \%$ \\
\hline Cetrix & $3.08 \mathrm{~mm}$ & $7.99 \mathrm{~mm}$ & $\begin{array}{l}2.39 \\
\mathrm{~kg} / \mathrm{cm} 2\end{array}$ & $\begin{array}{l}160 \\
\mathrm{mg}\end{array}$ & NMT $1 \%$ \\
\hline Instazin & $2.90 \mathrm{~mm}$ & $5.89 \mathrm{~mm}$ & $\begin{array}{l}3.2 \\
\mathrm{~kg} / \mathrm{cm} 2\end{array}$ & $\begin{array}{l}150 \\
\mathrm{mg}\end{array}$ & NMT $1 \%$ \\
\hline Tryzin & $3.11 \mathrm{~mm}$ & $4.03 \mathrm{~mm}$ & $\begin{array}{l}3.13 \\
\mathrm{~kg} / \mathrm{cm} 2\end{array}$ & $\begin{array}{l}140 \\
\mathrm{mg}\end{array}$ & NMT $1 \%$ \\
\hline
\end{tabular}

3.10. Dissolution Studies. Dissolution studies are conducted using a USP apparatus II, paddle type with $50 \mathrm{rpm}$ at $371 \mathrm{C}$. For standard preparation, about $10 \mathrm{mg}$ of cetirizine hydrochloride is placed in a $100 \mathrm{~mL}$ volumetric flask and dissolved with $0.1 \mathrm{M}$ hydrochloric acid and then the volume was made up to 
TABle 3. Physiochemical Parameter of cetirizine 2HCl Tablets

\begin{tabular}{|l|l|l|l|l|}
\hline $\begin{array}{l}\text { Brand } \\
\text { names }\end{array}$ & $\begin{array}{l}\text { Disintegration } \\
\text { time (minutes) }\end{array}$ & Rf values & $\begin{array}{l}\text { Dissolution test } \\
(\% \text { age })\end{array}$ & $\begin{array}{l}\text { Chemical } \\
\text { assay (\%age) }\end{array}$ \\
\hline Zyrtec & 4 minutes & 0.38 & $89.65 \%$ & $103 \%$ \\
\hline Alergo & 5 minutes & 0.38 & $85.74 \%$ & $102 \%$ \\
\hline Cetrix & 5 minutes & 0.38 & $87.95 \%$ & $106 \%$ \\
\hline Instazin & 22 minutes & 0.38 & $84.25 \%$ & $103 \%$ \\
\hline Tryzin & 2 minutes & 0.38 & $82.70 \%$ & $105 \%$ \\
\hline
\end{tabular}

$100 \mathrm{~mL}$ with $0.1 \mathrm{M}$ hydrochloric acid. $2 \mathrm{~mL}$ of this solution is transferred to another $100 \mathrm{~mL}$ volumetric flask and diluted to $100 \mathrm{~mL}$ with the same solvent. For the sample, about $900 \mathrm{~mL}$ of $0.1 \mathrm{~mL} \mathrm{HCl}$ was placed in the dissolution bowl with one tablet and the apparatus was started. The sample is drawn at time intervals of 5, 10, 15, 30 and 45 minutes for each formulation. Absorbance of the sample preparation and that of standard were taken at $220 \mathrm{~nm}$ using a $0.1 \mathrm{M}$ hydrochloric acid solution as a blank. Drug concentrations are measured spectrophotometrically. Results are shown in Table 3.

\section{Results and Discussion}

Price fluctuation among different brands of cetirizine $2 \mathrm{HCl}$ is given in Figure 1. Weight variation comparison of different brands of cetirizine $2 \mathrm{HCl}$ is given in Figure 2. Comparison of disintegration time of all the five samples is shown in Figure 3 and comparison of \% Assay of all the five samples is shown in Figure 4. It is evaluated by literatures that many drugs which are manufactured in developing countries are implicated to be substandard. In order to eliminate the health risk and provide the local community with affordable quality drugs, it is necessary to check the pharmaceutical services at regular basis. By providing this sort of information, people can make healthy choices according to their health problems. Relative to the quality of drug, the price fluctuation is also noticed in the societies where there is no regulatory control. In Figure. 1 the graphical representation shows that a significant variation in the cost of different brands containing same salt i.e. cetirizine $2 \mathrm{HCl}$ is present, whereas there is not a significant variation present in their quality. So its use can reduce the health expenses of a patient.

A drug becomes publically famous, by its effectiveness, immediate results and lesser side effects. The effectiveness in turn depends upon the content of active ingredients, disintegration time of drug, and its dissolution. All these parameters are controlled and monitored by Pharmaceutical quality control and quality assurance department. These departments check the composition and uniformity of the drug substances used in processing and in the final product. In case of above mentioned drugs from local pharmaceuticals, the traditional tests have been used to compare them with that of a multinational company. For this 
purpose, we conducted their physicochemical parameter's evaluation, to get a stable and effective drug product which may be pharmaceutically equivalent to a multinational product. The safety and efficiency of these drugs was measured by uniformity content. The amount of cetirizine $2 \mathrm{HCl}$ in the different local brands available in Lahore, is proved to be within limits, so these can replace a multinational brand at a low cost.

The present study is based on spectrophotometric method for chemical assay, TLC technique for the purity of API's and physiochemical parameters i.e. weight variation, hardness, friability, thickness and disintegration time as well as price fluctuation in PK rupees. Weight variation of the tablets were examined; all the tablets weight are in accordance with the required limit (NMT 5\%), hardness is tested; the hardness is in good agreement with the specification $(5-10 \mathrm{~kg} / \mathrm{cm} 2)$, thickness and the friability of the tablets are determined which complied with the specification ( $3.5 \mathrm{~mm}$ and NMT $1 \%$ ) respectively; disintegration test is performed, all the tablets were disintegrated with the prescribed time ( NMT 30 minutes); TLC technique is developed to check the quality and purity of API, all the active ingredients showed the similar $R_{f}$-values without any impurity $(0.38)$ ; pharmaceutical assay was carried out, none had potency less than the required specification ( $90 \%$ to $110 \%$ ).

From the comparative study, it is observed that all the brands of cetirizine $2 \mathrm{HCl}$, tablets $(10 \mathrm{mg})$ showed the same results as per I.P standards .Since there is a variation in the formulation of these drugs which may affect the results by performing qualitative and quantitative tests. From the test results and plots, it is observed and concluded that an economical and quality products can be prescribed for allergy patients whether they are manufactured by the local or multinational pharmaceutical companies without any health risk.

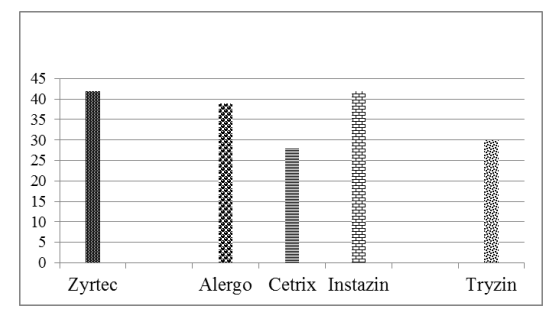

Figure 1. Price fluctuation among different brands of cetirizine $2 \mathrm{HCl}$.

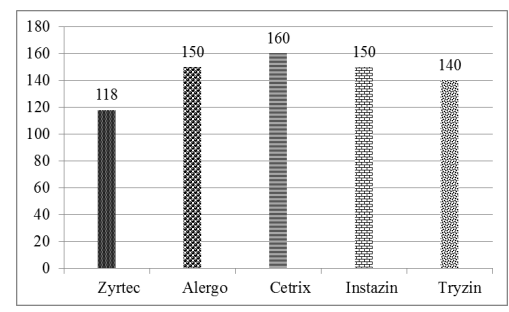

Figure 2. Weight variation comparison of different brands of cetirizine $2 \mathrm{HCl}$. 


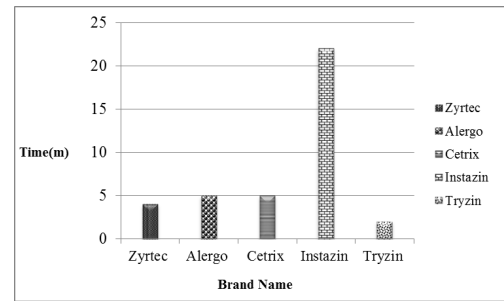

Figure 3. Comparison of disintegration time of all the five samples.

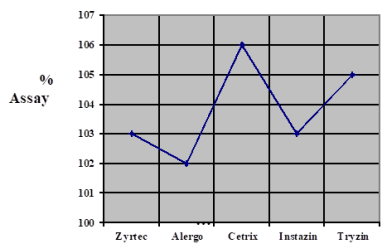

Figure 4. Comparison of \% Assay of all the five samples.

\section{Competing Interests}

The authors do not have any competing interests in the manuscript.

\section{REFERENCES}

1. Lachman, L., Lieberman, H. A., \& Kanig, J. L. (1976). The theory and practice of industrial pharmacy (pp. 210-212). Philadelphia: Lea \& Febiger.

2. Sing, D. K., Singh, R. A., (1998). The Eastern Pharmacist, 113.

3. Narayana Reddy, M., Sasira Reddy, K., Gowri sankar, D., \& Sreedhar, K. (1998). Spectrophotometric Determination Of Nimesulide. Eastern pharmacist, 41(483), 119-121.

4. Jaber, A. M. Y., Al Sherife, H. A., Al Omari, M. M., \& Badwan, A. A. (2004). Determination of cetirizine dihydrochloride, related impurities and preservatives in oral solution and tablet dosage forms using HPLC. Journal of pharmaceutical and biomedical analysis, 36(2), 341-350.

5. Parfitt, K. (1999). Analgesics, anti-inflammatory and antipyretics. Martindale: The Complete Drug Reference. 32nd ed, Massachusetts, 1-12.

6. Shakoor, O., Taylor, R. B., \& Behrens, R. H. (1997). Assessment of the incidence of substandard drugs in developing countries. Tropical Medicine 83 International Health, 2(9), 839-845.

7. Schweitzer, P. K., Muehlbach, M. J., \& Welsh, J. K. (1994). Sleepiness and performance during three-day administration of cetirizine or diphenhydramine. Journal of allergy and clinical immunology, 94(4), 716-724.

8. Jinquan, T., Reimert, C. M., Deleuran, B., Zachariae, C., Simonsen, C., ThestrupPedersen, K., \& for publication May, R. (1995). Cetirizine inhibits the in vitro and ex vivo chemotactic response of $\mathrm{T}$ lymphocytes and monocytes. Journal of allergy and clinical immunology, 95(5), 979-986.

9. Juhlin, L., \& Arendt, C. (1988). Treatment of chronic urticaria with cetirizine dihydrochloride a non-sedating antihistamine. British Journal of Dermatology, 119(1), 67-72.

10. Gennaro, A., \& Remington, R. (1995). The Science and Practice of Pharmacy. 19th edition. Eastern Pennsylvania: Mack Publishing Company. 
11. United State Pharmacopeia (USP) (2004) 27 United State Convention: pp. 2622-2625. United States Drug Enforcement Administration.

12. Arya, S. C. (1997). Quality control of essential drugs. The Lancet, 350(9084), 1106-1107. Sajid Mahmood

Division of Science and Technology, University of Education, Lahore 54590, Pakistan.

e-mail: drsajidue@gmail.com

Ammara Rafiq

Division of Science and Technology, University of Education, Lahore 54590, Pakistan.

Zaheer Ahmed

Department of Chemistry, University of Wah, Wah Cantt, Pakistan.

Muhammad Ajmal

Department of Chemistry, University of Wah, Wah Cantt, Pakistan. 